journal homepage: http://chimie-biologie.ubm.ro/carpathian_journal/index.html

\title{
HOVENIA DULCIS - DEVELOPMENT AND EVALUATION OF JELLY AND DEHYDRATED FRUIT
}

\author{
Gilson Gustavo Lucinda Machado ${ }^{1}$, Gilma Auxiliadora Santos Gonçalves ${ }^{1}$ \\ ${ }^{1}$ Federal Institute of Southeast Minas Gerais- Barbacena campus, Brazil \\ $凶_{\text {gilsonguluma@gmail.com }}$
}

https://doi.org/10.34302/crpjfst/2021.13.1.8

Article history:

Received:

8 September 2020

Accepted:

15 January 2021

Keywords:

Japanese grape;

Physical-chemical characteristics;

Bioactive compounds;

Phenolic compounds;

Texture.

\begin{abstract}
The aim of this study was to develop and evaluate Hovenia dulcis as jelly and dehydrated. The jellies were made in four formulations, following the steps of reception, selection and classification, washing and sanitizing, freezing, thawing, pre-tests, formulation, concentration, filling $/$ sealing of the packaging, cooling, labeling and storage. The dehydrated pseudofruit was prepared with four treatments according to, the following steps: defrosting, pre-treatments, dehydration $\left(70^{\circ} \mathrm{C}\right)$ from 90 to $120 \mathrm{~min}$., conditioning, packaging, labeling, storage. The products were characterized according to: color $\left(\mathrm{L}^{*}\right.$, $\mathrm{a}^{*}$ and $\mathrm{b}^{*}$ ), texture, $\mathrm{pH}$, soluble solids (SS), titratable acidity, moisture, ash, phenolic compounds, vitamin $\mathrm{C}$, and carotenoids. The prepared jellies showed good color and texture, high content of SS, total phenolics and vitamin C. Formulations F1 and F3 are more suitable, as they have more bioactive compounds. Dehydrated Hovenia dulcis showed high SS, ash, carotenoids, phenolic compounds and vitamin C, with treatments 3 and 4 being recommended.
\end{abstract}

\section{Introduction}

Hovenia dulcis Thunb, is a deciduous tree originating in East Asia and distributed mainly in China and Korea (Hyun et al., 2010). Its pseudofruits are globose, approximately $7 \mathrm{~mm}$ wide, with three seeds. When ripe the fruit is brown in color, the ripening phase occurring from late summer to autumn. When the contorted "fruit" stems are fully ripe, they are fleshy and sweet due to their high sucrose content (De Biaggi et al., 2019).

Studies have reported that Hovenia dulcis pseudofruits are a good alternative source to improve the nutritional quality of modern diets as they are a source of fiber, $\mathrm{Cu}, \mathrm{Ca}$ and $\mathrm{Mn}$ (Maieves et al., 2015). They also have health properties, among which the following stand out: antioxidant effect (considerable content of phenolic compounds, acids and tocopherols), anti-tumor, anti-diabetic and hepatoprotective. The fruit is also efficient at disinfection after alcohol intoxication, besides helping to prevent alcoholic steatosis and inflammation. It also has excellent colloidal properties with the potential to serve as a thickening, gelling and stabilizing agent, attributes that increase its potential for applicability in the food, pharmacological and cosmetic industries (Yang et al., 2020; Yang et al., 2019; Choi et al., 2017; Morales et al., 2017; Hyun et al., 2010).

Although the benefits of consuming Hovenia dulcis pseudofruit (popularly known as Japanese grape) are proven, there are few studies reporting its application as a raw material in the production of food products. Some studies indicate its use as a raw material in the preparation of alcoholic beverages (Pinto et al., 2017); cookies made from their fermented biomass (Cunha, Reineri \& Loss, 2015); dehydrated fruit (Maieves et al., 2015), justifying the performance of studies that expand its possibilities of processed 
consumption. Among these, jelly and dehydration can be highlighted.

Jelly is defined as a product obtained by cooking whole or in pieces, pulp or fruit juice, with sugar and water and concentrated to a gelling consistency. It must not be excessively sweet, sticky or viscous, and must retain the flavor and aroma of the original fruit, in addition to the consistency. When extracted from its container, the product must able to remain in the semi-solid state, without dripping ans be, soft when cutting, however firm (Brasil, 2005).

Jelly is consumed by a good part of the population because it presents a sweet and pleasant taste on the palate, which makes it widely accepted by consumers of different age groups, being part of important daily meals (Scolforo \& Silva, 2013).

Dried or dehydrated fruit, on the other hand, is defined as the product originating from the partial loss of water from the ripe fruit, whole or in pieces, by appropriate technological processes and with a maximum moisture of $25 \%$ (Brasil, 1978). In addition to increasing the product shelf life, dehydration provides a characteristic and refined flavor to vegetables, as with dried tomatoes, which have a high market price.

In this context, this work aimed to develop and evaluate jelly and pseudofruits from Hovenia dulcis.

\section{Materials and methods}

The work was carried out at the Federal Institute of Southeast Minas Gerais, campus Barbacena, industrialization and processing of vegetables, and a physical-chemical analysis laboratory.

\subsection{Materials}

\subsubsection{Obtaining and preparing the raw material}

The ripe pseudofruits collected from the Barbacena campus of IF Southeast MG, were selected and classified according to the stage of maturation (reddish brown color and slightly soft texture) and imperfections. After removing the seeds from the ends of the pseudofruits; washing was carried out under running water, sanitized in sodium hypochlorite solution (NaCIO) $100 \mathrm{mg} / \mathrm{L}$ for 10 minutes, packed in low density polyethylene (LDPE) plastic packaging, identification and freezer freezing ($\left.18^{\circ} \mathrm{C}\right)$. Freezing was necessary, since the pseudofruits are seasonal and obtained by extractivism, so it was possible to store a sufficient quantity for the pre-tests and development of the jelly and dehydrated fruit. Defrosting was performed in refrigeration and followed by pre-tests to define the best treatments.

\subsubsection{Manufacture of jellies}

After performing the pre-tests, the proportions of the ingredients were defined considering the legislation on ingredients and additives for the manufacture of fruit jellies. The jelly formulations are shown in table 1 .

Table 1. Formulations of Hovenia dulcis jellies

\begin{tabular}{|c|c|c|c|c|c|c|}
\hline Formulations & $\begin{array}{c}\text { Pulp } \\
(\%)\end{array}$ & Sugar (\%) & $\begin{array}{c}\text { Citric acid } \\
(\%)\end{array}$ & $\begin{array}{c}\text { Water } \\
(\%)\end{array}$ & $\begin{array}{c}\text { Orange } \\
\text { juice (\%) }\end{array}$ & Screening \\
\hline F1 & 79.7 & 20 & 0.3 & - & - & - \\
\hline F2 & 60 & 20 & 0.3 & 19.7 & - & Yes \\
\hline F3 & 60 & 20 & 0.3 & 19.7 & - & - \\
\hline F4 & 34.85 & 20 & 0.3 & 10 & 34.85 & Yes \\
\hline
\end{tabular}


The thawed pseudofruits were chopped and crushed to obtain the pulp. Then, the weighing and mixing process of the ingredients was started according to each formulation, cooking and concentration until the final point was obtained, observing the consistency that enables the formation of the gel. The jellies were packed in identified polyethylene containers and analyzed for color and texture on the same day of manufacture. The other samples, equally identified, were stored refrigerated until the other analyzes were carried out at a, maximum of 10 days.

\subsection{Manufacture of dehydrates}

The dehydrated products were prepared following the treatments shown in table 2 .

Table 2. Treatments applied to the pseudofruit of Hovenia dulcis for dehydration

\begin{tabular}{|c|c|}
\hline & Treatments \\
\hline 1 & Fresh fruit \\
\hline 2 & Water Vapor bleaching \\
\hline 3 & Water Vapor bleaching $+3 \%$ citric acid \\
\hline 4 & Water Vapor bleaching $+3 \%$ ascorbic acid \\
\hline
\end{tabular}

After defrosting the pseudofruits, dehydration was carried out using a temperature of $70^{\circ} \mathrm{C}$ for a time ranging from 90 to $120 \mathrm{~min}$. When the pseudofruits reached room temperature, they were packed in high density polyethylene packages and closed for 48 hours for moisture standardization, and the batches were identified with the corresponding and dated treatments, then they were stored refrigerated until the time of analysis by maximum 10 days.

\subsection{Analyzes performed on jellies and dehydrated fruit}

\subsubsection{Coloration}

Determined using a konica Minolta CR400 colorimeter, using the $\mathrm{L}^{*}, \mathrm{a}^{*}$ and $\mathrm{b}^{*}$ color scale system (CIELAB), previously calibrated.

\subsubsection{Texture}

Test conditions: a) jellies: cylindrical aluminum probe sensor with a diameter of one inch, test speed $2.0 \mathrm{~mm} / \mathrm{s}$, distance $10.0 \mathrm{~mm}$ and force $0.10 \mathrm{~N}$. For compression analysis, $5 \mathrm{~g}$ of jelly were used for each measurement. The parameters of firmness, cohesiveness, elasticity, adhesiveness, guminess and chewability were evaluated (Pons \& Fiszman, 1996). b) dehydrated: Probe TA39 (cylindrical), pre-test, test speed, post-test of $5.0 \mathrm{~mm} / \mathrm{s}$, penetration distance of $5.0 \mathrm{~mm}$, time of $5.00 \mathrm{~s}$ and contact force of $1 \mathrm{~g}$.

Only the firmness parameter, expressed in Newton, was considered.

\subsection{3. $\mathrm{pH}$}

TEKNA T-1000 pH-meter was used according to the methodology proposed by Instituto Adolfo Lutz (IAL, 2008). The $\mathrm{pH}$ meter was previously calibrated using buffer solutions ( $\mathrm{pH} 4.0$ and 7.0).

\subsubsection{Titratable acidity}

Determined by titration with standardized $0.1 \mathrm{~N}$ sodium hydroxide solution, using phenolphthalein as an indicator. According to the methodology proposed by the Analytical Standards of (IAL, 2008).

\subsubsection{Soluble solids (\% SS)}

Determined by refractometry using an IONLAB benchtop refractometer (evem).

\subsubsection{Moisture}

Made by gravimetry in a drying oven and sterilization Deleo A4SE sterilization at $105^{\circ} \mathrm{C}$ until constant dry mass, according to the Instituto Adolfo Lutz (IAL, 2008). 


\subsubsection{Ash}

Made after incineration in a $550^{\circ} \mathrm{C}$ muffle, by gravimetry according to the Adolfo Lutz Institute (IAL, 2008).

\subsubsection{Total phenolic compounds}

The extracts were obtained as described by Brand Williams; Cuvelier and Berset (1995) and adapted by Rufino et al. (2007) and determined as described by Waterhouse (2002). Gallic acid was used as a reference standard and the results were expressed in milligrams of gallic acid equivalents (mg GAE $100 \mathrm{~g}-1$ fresh matter).

\subsubsection{Vitamin C}

Determined by the Balentine method, which is based on the oxidation of ascorbic acid by potassium iodate (Tavares, 1999).

\subsubsection{Total carotenoids}

Carotenoid extraction and determination were performed as described by RodriguezAmaya (1999).

Experimental design and statistical analysis: Dehydrated pseudofruits and jellies were prepared with 4 treatments, with 3 repetitions and the results were submitted to analysis of variance. When there was a significant difference $(p<0.05)$, the averages were compared using the Tukey test at 5\% significance using the Sisvar 5.3 program (Ferreira, 2010).

\section{Results and discussions}

The results of the physical analysis of the Hovenia dulcis pseudofruit jellies are shown in Table 3.

Table 3. Physical characterization of Hovenia dulcis jellies

\begin{tabular}{|c|c|c|c|c|}
\hline Parameters & F1 & F 2 & F 3 & F 4 \\
\hline Color & & & & \\
\hline $\mathrm{L}^{*}$ & $34.33 \mathrm{a}$ & $36.61 \mathrm{a}$ & $34.57 \mathrm{a}$ & $33.94 \mathrm{a}$ \\
\hline $\mathrm{a}^{*}$ & $8.57 \mathrm{a}$ & $8.71 \mathrm{a}$ & $8.73 \mathrm{a}$ & $9.68 \mathrm{a}$ \\
\hline $\mathrm{b}^{*}$ & $13.95 \mathrm{a}$ & $19.79 \mathrm{a}$ & $16 \mathrm{a}$ & $15.40 \mathrm{a}$ \\
\hline Firmness (N) & $5.65 \mathrm{a}$ & $5.33 \mathrm{a}$ & $5.35 \mathrm{a}$ & $0.92 \mathrm{~b}$ \\
\hline Adhesiveness (N) & $-10.25 \mathrm{a}$ & $-9.80 \mathrm{a}$ & $-7.84 \mathrm{a}$ & $-2.28 \mathrm{~b}$ \\
\hline Elasticity (N) & $0.0095 \mathrm{a}$ & $0.0091 \mathrm{a}$ & $0.0094 \mathrm{a}$ & $0.0092 \mathrm{a}$ \\
\hline Chewability (N) & $5.57 \mathrm{a}$ & $4.29 \mathrm{a}$ & $4.12 \mathrm{a}$ & $0.61 \mathrm{~b}$ \\
\hline Gumness (N) & $5.74 \mathrm{a}$ & $4.03 \mathrm{a}$ & $5.61 \mathrm{a}$ & $0.65 \mathrm{~b}$ \\
\hline Cohesiveness (N) & $0.0083 \mathrm{a}$ & $0.0081 \mathrm{a}$ & $0.0076 \mathrm{a}$ & $0.0070 \mathrm{a}$ \\
\hline
\end{tabular}

Means followed by the same letters on the line are statistically equal by the Tukey test at $5 \%$ significance.

The parameter $L^{*}$ that represents (luminosity or clarity), varying from white ( $\mathrm{L}^{*}$ $=100)$ to black $\left(\mathrm{L}^{*}=0\right)$ did not differ statistically between the formulations analyzed (average of 34.86) indicating that the jellies were dark, which was expected considering the characteristic brown color of the fruit, associated with cooking heat that favors oxidation reactions of ascorbic acid and Caramelization, resulting in browning (Fellows, 2006). Curi et al. (2017) when analyzing jam from different loquat cultivars, reported $\mathrm{L}^{*}$ values ranging from 52.47 $-76.03$.

Positive values of $\mathrm{a}^{*}$ indicate reddish color, and when negative indicate green color. The prepared jellies showed no statistical difference regarding this parameter (mean of 8.92) indicating that they have a reddish color. Curi et al. (2017) when analyzing jam from different loquat cultivars, report values varying between 1.23-8.35 for the same parameter, thus Hovenia dulcis jelly has a color similar to that of loquat jelly.

The value of $b^{*}$, when, positive indicates yellow color and when negative, blue. There was no difference between the jellies analyzed for this variable (average of 16.28). Curi et al. (2017) when analyzing jam from different loquat cultivars, report values ranging from 6.27 - 33.53 for the same parameter. These results 
showed that the jelly staining parameters are specific to each species and influenced by the heat treatments applied.

Instrumental firmness is defined as the force necessary to obtain a certain deformation, however in sensory analysis it is described as being the force necessary to compress a substance between the teeth (molars, when it comes to solids) or between the tongue and the palate (when semi-solid) (Szczesniak, 2002). The jam from treatment F4 (with the addition of orange juice) differed from the others with a firmness of 0.92 N. Lemos et al. (2019), when analyzing the mixed prebiotic jabuticaba and acerola jelly, obtained values ranging from 0.96 to $4.60 \mathrm{~N}$. Already Vieira et al. (2017), reports higher values ranging from 10.11-13.69 N, for the same parameter when evaluating mixed jabuticaba and pitanga jam.

Adhesiveness is related to the force expended to remove material adhered to the mouth during chewing (Szczesniak, 2002). Only the F4 treatment jelly differed from the others in terms of adhesion.

Elasticity, the ability of a deformed material to return to its initial state after removing the deformation force (Szczesniak, 2002), did not show any difference between the formulations elaborated. Higher values for the same parameter are reported by Lemos et al. (2019), when analyzing the mixed prebiotic jabuticaba and acerola jelly, who describes values ranging from 0.98 to $1 \mathrm{~N}$ for this parameter.

The energy required to chew a solid food to a state capable of swallowing, defines chewability (Szczesniak, 2002). Only the F4 treatment differed from the other formulations analyzed regarding this parameter. The values for this parameter, with the exception of formulation 4, are higher than those reported by Lemos et al. (2019), when analyzing the mixed prebiotic jabuticaba and acerola jelly, which obtained values ranging from 0.33 to $2.04 \mathrm{~N}$.

Gumminess can be understood as the energy necessary to disintegrate a semi-solid food at a stage where it is able to swallow (being a product with a low degree of hardness and a high degree of cohesion (Szczesniak, 2002). The F4 treatment jelly differed from the other formulations. The results of the present study are superior to those described by Lemos et al. (2019), when analyzing the mixed prebiotic jabuticaba and acerola jelly, which reports values ranging from 0.33 to $1.97 \mathrm{~N}$.

Table 4. Physico-chemical characterization and bioactive compounds of Hovenia dulcis jellies

\begin{tabular}{|c|c|c|c|c|}
\hline Parameters & F1 & F2 & F3 & F4 \\
\hline $\mathrm{pH}$ & $4.97 \mathrm{a}$ & $4.78 \mathrm{a}$ & $5.03 \mathrm{a}$ & $4.72 \mathrm{a}$ \\
\hline Titratable acidityl - AT $(\mathrm{g} / 100 \mathrm{~g})$ & $0.29 \mathrm{a}$ & $0.36 \mathrm{a}$ & $0.24 \mathrm{a}$ & $0.29 \mathrm{a}$ \\
\hline Soluble solids - SS $(\mathrm{g} / 100 \mathrm{~g})$ & $76.4 \mathrm{a}$ & $73.73 \mathrm{ab}$ & $69 \mathrm{a}$ & $71.20 \mathrm{ab}$ \\
\hline Humidity $(\mathrm{g} / 100 \mathrm{~g})$ & $56.38 \mathrm{a}$ & $52.94 \mathrm{ab}$ & $50.90 \mathrm{~b}$ & $53.22 \mathrm{ab}$ \\
\hline Ashes $(\mathrm{g} / 100 \mathrm{~g})$ & $1.47 \mathrm{ab}$ & $1.56 \mathrm{ab}$ & $1.73 \mathrm{a}$ & $1.21 \mathrm{~b}$ \\
\hline Phenolics $(\mathrm{mg} \mathrm{GAE} 100 \mathrm{~g})$ & $1960.59 \mathrm{ab}$ & $1489.27 \mathrm{c}$ & $2328.03 \mathrm{a}$ & $1767.26 \mathrm{bc}$ \\
\hline Vitamin C (mg/100 g) & $21.51 \mathrm{a}$ & $25.43 \mathrm{a}$ & $17.60 \mathrm{a}$ & $19.55 \mathrm{a}$ \\
\hline Carotenoids $(\mathrm{mg} / 100 \mathrm{~g})$ & $121.52 \mathrm{a}$ & $47.16 \mathrm{c}$ & $74.02 \mathrm{a}$ & $15.56 \mathrm{c}$ \\
\hline
\end{tabular}

Means followed by the same letters, are statistically equal by Tukey's test at 5\% significance. Formulation 1 (jelly without added water), Formulation 2 (jelly with added water and sieving), Formulation 3 (jelly with added water and no sieving), Formulation 4 (jelly with added water, sieving and added juice) orange)

Cohesiveness is defined as the level of deformation of the sample between the teeth until its rupture, or the maximum level of deformation supported by the food until its rupture (Szczesniak, 2002). There was no significant difference between the samples under study. The values obtained in this study are lower than those reported by Vieira et al. (2017), who obtained values ranging from 0.44 $0.69 \mathrm{~N}$, for the same parameter when evaluating mixed jabuticaba and pitanga jelly, and by Lemos et al. (2019), when analyzing the mixed 
prebiotic jabuticaba and acerola jelly, who report values ranging from 0.34 to $0.52 \mathrm{~N}$.

The texture of the jellies was similar, as were most parameters, with only formulation 4 highlighted, the only one with added with orange juice, which possibly was a determinant of the differences observed.

The formulations studied did not differ from each other, regarding the $\mathrm{pH}$ parameter, obtaining an average of 4.87; a lower value is reported by Ribas, Buratto and Pereira (2017) when analyzing Thompson Seedless grape jelly, who report a value of 3.53 for the same parameter.

There was no difference between the jellies studied in terms of titratable acidity, obtaining an average of $0.29 \mathrm{~g} / 100 \mathrm{~g}$ of citric acid. Higher values for the same parameter are reported by Ribas, Buratto and Pereira (2017), when analyzing Thompson Seedless grape jelly $(0.75$ $\mathrm{g} / 100 \mathrm{~g}$ ), Vieira et al. (2017), in mixed pineapple peel and peach pulp jelly $(0.40 \mathrm{~g} / 100 \mathrm{~g})$. The higher acidity in jellies can be influenced, among other factors, by the original acidity of the raw material, which in this case favored the lower acidity of the jellies. This characteristic can be altered by new studies to improve the formulations of pseudofruit jellies, using percentages greater than $0.3 \%$ of citric acid.

The levels of soluble solids did not differ between the formulations under study, obtaining an average of $72.58 \mathrm{~g} / 100 \mathrm{~g}$, so all formulations are in accordance with that established by the Brazilian Standard of Identity and Quality of jams and fruits (Brasil, 1978), which stipulates a minimum total solids content of 62-65 g/100 g. A little lower value for the same parameter is reported by Ribas, Buratto and Pereira (2017), when analyzing Thompson Seedless grape jelly which obtained a value of $69 \mathrm{~g} / 100 \mathrm{~g}$ for SS. Considering that Hovenia dulcis has high sugar content, this characteristic certainly favored the high content of soluble solids in jellies. However, further studies to improve the formulation can be done, because even the proportion of the lowest sugar content used in the formulations $(20 \%)$, previously defined in pre-tests, can be reduced, complying with
Brazilian legislation and additionally obtaining final product with less caloric value, characteristic of healthiness currently sought by consumers.

As for moisture, all formulations had a higher content than that defined by the Brazilian Standard of Identity and Quality of fruit jellies regarding this parameter (Brasil, 1978), which defines a maximum moisture content of 38 g/100 g. Lower values are reported by Ribas, Buratto and Pereira (2017), when analyzing Thompson Seedless grape jelly which obtained a value of $30.49 \mathrm{~g} / 100 \mathrm{~g}$ for moisture. Higher moisture levels are related to greater ease of alteration of the final product, since it allows greater water activity, compromising the product' durability.

Regarding the ash content, formulations F3 and F4 were statistically different, which can be justified by the addition of orange juice in formulation F4, which diluted the sample and favored lower ash content. A similar value for the same parameter is reported by Vieira et al. (2017) in mixed pineapple peel and peach pulp jelly $(1.44 \mathrm{~g} / 100 \mathrm{~g})$ and a lower value is described by Ribas, Buratto and Pereira (2017), when analyzing Thompson Seedless grape jelly which obtained $0,49 \mathrm{~g} / 100 \mathrm{~g}$ of ash. This demonstrates that jams made with Hovenia dulcis can be significant sources of minerals.

The jams of the Hovenia dulcis pseudofruit showed high levels of phenolic compounds. Formulations F1 and F3 are statistically equal and have the highest levels of these compounds. When comparing its values with other studies, even the jelly with the lowest phenolic content, formulation F2 presented a content (1489.27 $\mathrm{mg} / 100 \mathrm{~g}$ ) higher than that of other jellies, such as araçá red $(117.59 \mathrm{mg} / 100 \mathrm{~g})$ (Reissig et al., 2016); palm jelly (Butia odorata Barb. Rodr.) in Which values ranging from 280.5 to 398.50 $\mathrm{mg} / 100 \mathrm{~g}$ were found (Beskow et al., 2015).

The vitamin $\mathrm{C}$ content did not vary statistically between the jelly formulations. The results of this study showed that pseudofruit jams have higher levels of vitamin $C$ than mixed umbu and mangaba jams ( 1.7 to $1.9 \mathrm{mg} / 100 \mathrm{~g}$ ); passion fruit jelly with flaxseed (average of 3.61 
mg/100 g) (Souza et al., 2018; Moura et al., 2019) and that bocaiuva jelly with passion fruit (1.70 to $3.61 \mathrm{mg} / 100 \mathrm{~g}$ ) (Souza et al., 2019). In this sense, it can be said that the jam of the pseudofruit of Hovenia dulcis is an important source of vitamin $\mathrm{C}$.

Formulations F1 and F3 are statistically equal and have the highest levels of carotenoids (average of $97.77 \mathrm{mg} / 100 \mathrm{~g}$ ) in the jellies. The carotenoid values found in the present study are higher than those of passion fruit jelly with flaxseed seed $(0.02 \mathrm{mg} / 100 \mathrm{~g})$, bocaiuva jam with passion fruit $(11.44 \mathrm{mg} / 100 \mathrm{~g})$, and palm jelly (Butia odorata Barb Rodr.) (2.8 to 4.08 $\mathrm{mg} / 100 \mathrm{~g}$ ) (Moura et al., 2019; Souza et al., 2019; Beskow et al., 2015).

In general, formulations without sieving ( F1 and F3) had a higher content of phenolic and carotenoid compounds when compared to those that underwent such process (F2 and F4). This is possibly because most of the simple phenolics, which represent a large part of the plant phenolics, have relatively low molecular weight and variable solubility depending on the polarity and chemical structure. Some phenolic compounds, however, can be attached to the cell wall. Depending on the nature of the ester bonds, such compounds can be solubilized in alkaline conditions or can be retained in the fiber matrix (Bravo, 1998). Either way, in both cases, the sieving can induce the elimination of bioactive compounds adhered to the fibers by different types of chemical bonds and forces of attraction, consequently decreasing these compounds in sieved foods in general.

The dehydratyed Hovenia dulcis analyzes are shown in Table 5.

Table 5. Analysis of dehydratyed Hovenia dulcis according to the treatments applied

\begin{tabular}{|c|c|c|c|c|}
\hline Parameters & T 1 & T 2 & T 3 & T 4 \\
\hline Color & & & & \\
\hline $\mathrm{L}^{*}$ & $33.66 \mathrm{a}$ & $31.48 \mathrm{~b}$ & $31.78 \mathrm{~b}$ & $31.29 \mathrm{~b}$ \\
\hline $\mathrm{a}^{*}$ & $3.32 \mathrm{a}$ & $2.39 \mathrm{a}$ & $2.91 \mathrm{a}$ & $2.04 \mathrm{a}$ \\
\hline $\mathrm{b}^{*}$ & $4.93 \mathrm{a}$ & $3.27 \mathrm{~b}$ & $4.06 \mathrm{a} \mathrm{b}$ & $3.22 \mathrm{~b}$ \\
\hline Firmness $(\mathrm{N})$ & $1.67 \mathrm{a}$ & $1.49 \mathrm{a}$ & $1.36 \mathrm{a}$ & $1.52 \mathrm{a}$ \\
\hline $\mathrm{pH}$ & $5.66 \mathrm{a}$ & $5.61 \mathrm{a}$ & $5.51 \mathrm{a}$ & $5.57 \mathrm{a}$ \\
\hline Titratable acidity $(\mathrm{g} / 100 \mathrm{~g})$ & $0.10 \mathrm{a}$ & $0.10 \mathrm{a}$ & $0.14 \mathrm{a}$ & $0.10 \mathrm{a}$ \\
\hline Soluble solids $(\mathrm{g} / 100 \mathrm{~g})$ & $60 \mathrm{a}$ & $60 \mathrm{a}$ & $60 \mathrm{a}$ & $60 \mathrm{a}$ \\
\hline Humidity $(\mathrm{g} / 100 \mathrm{~g})$ & $44.55 \mathrm{a}$ & $44.01 \mathrm{a}$ & $38.03 \mathrm{a}$ & $39.51 \mathrm{a}$ \\
\hline Ashes $(\mathrm{g} / 100 \mathrm{~g})$ & $3.34 \mathrm{a}$ & $3.44 \mathrm{a}$ & $3.88 \mathrm{a}$ & $3.56 \mathrm{a}$ \\
\hline Phenolics $(\mathrm{mg}$ GAE $100 \mathrm{~g})$ & $17.21 \mathrm{~b}$ & $9.24 \mathrm{~b}$ & $72.77 \mathrm{a}$ & $27.21 \mathrm{~b}$ \\
\hline Vitamin C (mg $100 \mathrm{~g})$ & $5.87 \mathrm{a}$ & $5.86 \mathrm{a}$ & $5.86 \mathrm{a}$ & $5.86 \mathrm{a}$ \\
\hline Carotenoids $(\mathrm{mg} / 100 \mathrm{~g})$ & $10.12 \mathrm{a}$ & $5.41 \mathrm{~b}$ & $6.32 \mathrm{ab}$ & $7.09 \mathrm{ab}$ \\
\hline
\end{tabular}

Averages followed by the same letters on the line are statistically equal by the Tukey test at 5\% significance. T1-Treatment 1 (in natura), T2-Treatment 2 (Water vapor), T3-Treatment 3 (Water vapor + citric acid), T4-Treatment 4 (water vapor + ascorbic acid).

The results of the $\mathrm{L}^{*}$ value that expresses the luminosity or clarity of the sample indicated that only $\mathrm{T} 1$ differed statistically from the other treatments, presenting a higher $\mathrm{L}^{*}$ value, indicating that dehydrated in natura, that is, without any pre-treatment, presented lighter color compared to other treatments.

Considering the scarcity of works in the literature evaluating the dehydrated Japanese grape, this work will be compared with the traditional raisin, as this is the fruit that most resembles the dried Hovenia dulcis.

Melo et al. (2018) when studying the grape raiseing BRS Victory, submitted to drying methods for obtaining raisins, reported $\mathrm{L}^{*}$ value of 25.26, indicating that the dehydrated grape have a darker color compared to the dehydrated pseudofruits from Hovenia dulcis. 
As for the results of the value of $a^{*}$, the treatments are statistically equal, indicating that dehydrated Hovenia dulcis passes has a reddish color regardless of the treatment applied. Melo et al. (2018) report a value of 5.67 for the same parameter when evaluating raisins.

The $b^{*}$ value of dehydrated pseudofruits showed that $\mathrm{T} 1$ was statistically equal to T3, differing from the other treatments (T2 and T4). The results for this parameter are similar to those of Melo et al. (2018) for raisins, who reported a $\mathrm{b}^{*}$ value of 3.59 , showing the similarity in color of Hovenia dulcis raisin with raisin.

Firmness was not influenced by the treatments applied, with an average of $1.51 \mathrm{~N}$. Melo et al. (2018) when evaluating raisins (BRS Victory) reports lower average firmness than this study $(0.23 \mathrm{~N})$. Considering that texture is an important attribute of influence in the acceptance of processed fruits and vegetables, it would be interesting to evaluate the sensorial acceptance of dehydrated Hovenia dulcis as a way to evaluate its possible introduction in the consumer market of dehydrated fruits.

Regarding $\mathrm{pH}$, there was no difference between the treatments under study, obtaining an average of 5.58, and it can be inferred that both the use of citric acid or ascorbic acid in the steam-forming water did not influence this parameter. This $\mathrm{pH}$ is higher than that reported by Martineli et al. (2018) when analyzing three cultivars processed raisins produced in the semiarid region of Brazil (4.51-5.56), Machado, Souza and Novaes (2015), when analyzing Isabel pass (4.13), and Melo et al. (2018) when analyzing BRS Victory raisins (4.03), this may be due to the low natural acidity of the fresh pseudofruit.

The titratable acidity of dehydrated Hovenia dulcis did not differ statistically between treatments, obtaining an average of $0.14 \mathrm{~g} / 100$ $\mathrm{g}$, correlating with the $\mathrm{pH}$ value found. Higher value for the same parameter is reported by Melo et al. (2018), when analyzing BRS Victory raisins (2.10 g/100 g), Machado, Souza and Novaes (2015), when analyzing Isabel grape raisin (1.31 g/100 g); and Slva et al (2015), when analyzing the Crimson grape raisin $(2 \mathrm{~g} / 100 \mathrm{~g})$.
This variation can be justified by intrinsic differences specific to each species of fruit evaluated.

The soluble solids content did not vary ( $p$ $<0.05)$ between the treatments under study (average of $60 \mathrm{~g} / 100 \mathrm{~g}$ ). The higher SS content in dehydrated foods is due to the concentration of sugars and organic acids due to the loss of water that occurs during dehydration. The result of this research is much higher than that reported by Silva et al. (2015), (17.3g/100 g of SS) when analyzing the dehydrated Crimson grape, and by Machado, Souza and Novaes (2015), when analyzing the Isabel grape raisin $(46.38 \mathrm{~g} / 100 \mathrm{~g}$ of SS), and lower than that reported by Melo et al. (2018), when analyzing BRS Victory grape raisins $(66.3 \mathrm{~g} / 100 \mathrm{~g})$, this difference can be justified by the differences in the species evaluated, in the cultivars, soil type, climate and, cultural treatments, among others.

Regarding moisture, there was no statistical difference between the treatments under study (average $32.53 \mathrm{~g} / 100 \mathrm{~g}$ ), however it was higher than that indicated in the Brazilian legislation (Brasil, 2005), which stipulates a maximum of $25 \mathrm{~g} / 100 \mathrm{~g}$ for dried or dehydrated fruits. However, considering the higher firmness identified in the dehydrated pseudofruit, when compared to previously presented studies on dehydrates, lower moisture content could negatively influence the sensory acceptance of this product. On the other hand, lower moisture values are reported for the Isabel raisin (19.87 $\mathrm{g} / 100 \mathrm{~g}$ ) (Machado, Souza \& Novaes, 2015).

The studied samples were statistically equal in relation parameter Ashes (average $3.55 \mathrm{~g} /$ $100 \mathrm{~g}$ of ash).

The levels of phenolic compounds in treatment T3 (water vapor + citric acid) were statistically higher than other treatments. A higher value for the same parameter is reported by Melo et al. (2018), when analyzing $B R S$ Victory raisins $(254.55 \mathrm{mg} / 100 \mathrm{~g})$. The author states that the increase in temperature and the discontinuity of the tissue, promoted by heating, increase the bioavailability of compounds with antioxidant activity. Interestingly, when comparing the phenolic content of the 
treatments applied in the pseudofruit jelly formulations (Table 2), we observe much higher values than for the pseudofruit in the dehydrated form. Tjis makes, it possible to infer that the combination of ingredients, association with sugar, crushing or shorter heating time (average of $30 \mathrm{~min}$ for jellies) favored greater extraction or retention of these compounds.

Regarding vitamin $\mathrm{C}$, there was no significant difference between the treatments under study (average of $5.86 \mathrm{mg} / 100 \mathrm{~g}$ ). The low content of vitamin $\mathrm{C}$ in dehydrated pseudofruits may be due to the high instability of this compound under heating processes such as that used by a cabin dehydrator with an air system heated to $70{ }^{\circ} \mathrm{C}$ used in the elaboration of the studied treatments. When comparing with the results found for jellies (Table 2), there are also higher levels of vitamin $\mathrm{C}$ in jellies (average $21.02 \mathrm{mg} / 100 \mathrm{~g}$ ) than in dehydrated pseudofruits.

The carotenoid content of the dehydrated pseudofruit varied between the treatments applied, with the $\mathrm{T} 2$ treatment being statistically lower $(5.41 \mathrm{mg} / 100 \mathrm{~g}$ than the others (average of $7.84 \mathrm{mg} / 100 \mathrm{~g})$. Possibly the bleaching process (T2, T3 and T4) may have influenced the color and the phenolic compounds content of the dehydrateds, and treatment 3 retained a higher content of phenolic compounds.

In general, when comparing the content of bioactive compounds studied, it can be indicated that the pseudofruit in the form of jelly favors a higher content of these compounds than when in the dehydrated form.

\section{Conclusions}

The jellies made with the pseudofruit of Hovenia dulcis showed good color, texture, high content of soluble solids, ash and bioactive compounds, phenolic compounds, vitamin C and carotenoids, with emphasis on formulations F1 and F3 because they have a higher content of bioactive compounds.

The elaborated dehydrated Hovenia dulcis had a high content of SS and ash and a good source of carotenoids, phenolic compounds and vitamin $C$. Treatments 3 and 4 obtained a higher content of bioactive compounds, these treatments being the most indicated. Aiming at a higher content of bioactive compounds, the processing of the pseudofruit in the form of jelly should be preferred.

Further studies are recommended for the development and improvement of jam and dehydrated Hovenia dulcis and also the sensory analysis of the products to adjust the formulations in order to meet consumer expectations.

\section{References}

Beskow, G. T., Hoffmann, J. F., Teixeira, A. M., Fachinello, J. C., Chaves, F. C., Rombaldi, C. V (2015). Bioactive and yield potential of jelly palms (Butia odorata Barb. Rodr.) Food Chemistry, 172, 699-704.

Brand-Williams, W., Cuvelier, M.E., Berset, C (1995). Use of a free radical method to evaluate antioxidant activity. Food Science and Technology, 28, 25-30.

Brasil. Agência Nacional de Vigilância Sanitária ANVISA. (1978). Resolução CNNPA. $\mathrm{N}^{0} 12$, de 24 de junho de 1978. Resolução Geral de Alimentos. Diário Oficial da República Federativa do Brasil, Brasília, Seção 1, p. 1-75.

Brasil. Agência Nacional de Vigilância Sanitária ANVISA. (2005). Resolução $n^{\circ} 272$, de 22 de setembro de 2005. Regulamento técnico para produtos de vegetais, produtos de frutas e cogumelos comestíveis. Diário Oficial da União, Brasília, DF, 22 de dezembro de 2005.

Bravo, L. (1998). Polyphenols Chemistry, Dietary sources, metabolism, and nutritional significance. Nutrition Reviews, 58 (11), 317-333.

Choi, R-A., Woo M. J., Ham, J. R., Lee, M. K. (2017). Anti-statotic and anti-inflammatory effects of Hovenia dulcis Thunb. extracts in chronic alcohol-fed rats. Biomedicine $e$ Pharmacotherapy. Korea, 90, 393-401.

Cunha, M. A. A., Reineri, D. \& Loss, E. M. S. (2015). Cookies formulados com biomassa fermentada de uva-do-japão: uma nova proposta de aproveitamento. Revista 
Brasileira de Pesquisa em Alimentos, 6 (1),26-36.

Curi, P. N., Nogueira, P. V., Almeida, A. B. de, Carvalho, C. dos S., Pio, R., Pasqual, M., Souza, V. R. de (2017). Processing potential of jellies from subtropical loquat cultivars. Food Science and Technology,37, 70-75.

De Biaggi, M., Donno, D., Mellano, M. G., Gamba, J., Alagado, I., Rakotoniaina, E. N., Beccaro, G. L (2019). Emerging species with nutraceutical properties: Bioactive compounds from Hovenia dulcis pseudofruits. Food Chemistry, 310,1-16.

Fellows P. J. (2006). Tecnologia do processamento de alimentos: princípios e prática. Porto Alegre :2a. ed, Artmed.

Ferreira, D. F. SIVAR- Sistema de análise de variância. Versão 5.3. Lavras- MG: UFLA, 2010.

Hyun, T. K., Eom, S. H., Yu, C. Y., (2010). Roitsch, t. Hovenia dulcis - An Asia Tradicional Herb. Mini Reviews, 76, 943949.

Instituto Adolfo Lutz - IAL. (2008). Métodos Físico-Químicos para Análise de Alimentos. 4. ed. São Paulo.

Lemos, D. M., Rocha, A. P. T., Gouveia, J, P G de, Olivera, E. N. A de, Sousa, E. P de, Silva, S. F. da. (2019). Elaboração e caracterização de geleia prebiótica mista de jabuticaba e acerola. Revista Brazilian Journal of Food Technology, 22, 1-13.

Machado, A. V., Souza, J. A. de, \& Novaes, R. da S. (2015). Estudo cinético da secagem da uva Isabel para produção de uva passa. Revista Verde de Agroecologia e Desenvolvimento sustentável. 10 (1), 47-51.

Maieves, H. A, Ribani, R. H., Morales, P. Sánchez-Mata, M. de C. (2015). Evolution of the nutritional composition of Hovenia dulcis Thunb. Pseudofruit during the maturation process. Fruits. Madrid. 70 (3), 181-187.

Martineli, M., Santos, J. R. P dos, Maranhão, C. M. de A., Castricini, A. (2018). Avaliação sensorial e da qualidade de uvas-passas processadas a partir de três cultivares produzidas no semiárido. Brazilian Journal of Food Technology, 21, e 2017131.

Melo, A. P. C. de, Rybka, A. C. P., Freitas, S. T. de, Biasoto, A. C. T., Nassur, R. de c. M. R. (2018). Influência de métodos de secagem na qualidade de uvas passas produzidas na região semiárida brasileira. Revista brasileira de produtos Agroindustriais, 20 (2), 103-110.

Morales, P., Maieves, H. A., Dias, M I., Calhella, R. C., Sánchez-Mata, M. C., Santos-Buelga, C., Barros, L., Ferreira, I. C. F. R. F. (2017). Hovenia dulcis Thunb. pseudofruits as functional foods: Phytochemical and bioactive properties in different maturity stages. Journal of Functional Foods, Spain, 29, 37-45.

Moura, H. V., Silva, E. T de V., Figueirêdo, R. M. F. de, Moreira, I. dos S., Queiroz, A. J. de M. (2019). Produção e caracterização de geleias de maracujá com sementes de linhaça marron. Revista Brasileira de Higiene e Sanidade Animal,13 (2),218-229.

Pinto, J. T., Alvarenga, L. F., Oliveira, D. P de, Oliveira, T. T. de, Schwan, R. F., Dias, D. R., Queiroz, J. H. de. (2017). Elaboration and characterization of Japanese Raisin Tree (Hovenia dulcis Thumb.) pseudofruits fermented alcoholic beverage. Food Science and Technology, 37 (suppl. 1), 101-108.

Pons M., \& Fiszman S. M. (1996). Instrumental texture profile analysis with particular reference to gelled systems. Journal of texture studies, 27 (6), 597- 694.

Reissig, G. N., Vergara, L. P., Franzon, R. C., Rodrigues, R. DA S., Chim, J. F. (2016). Bioactive compounds in conventional and no added sugar red strawberry guava (Psidium cattleianum Sabine) Jellies. Revista Brasileira de Fruticultura, 38 (3), 17.

Ribas, M. F., Buratto, A. P., \& Pereira, E. A. (2017). Desenvolvimento de geleia de uva "Thompson Seedless". Revista Synergismus scyentifica UTFPR, 12 (1), 109-117.

Rodriguez-Amaya, D. B. (1999). A guide to carotenoids analysis in foods. Washington: Ilsi. 
Rufino $\mathrm{M}$ do S M, Alves R E, Brito E S de, Morais S M de, Sampaio C de G, PérezJiménez J, Saura-Calixto f D (2007). Metodologia científica: determinação da atividade antioxidante total em frutas pela captura do radical livre DPPH. Comunicado Técnico 127. Embrapa, Fortaleza, Brasil.

Scolforo, C. Z., \& Silva, E. M. M. da. (2013). Elaboração de geleia de maçã enriquecida com fruto oligossacarídeo. Revista. Alim. Nutr., 24 (1), 115-125.

Souza, H. R. S. de, Santos, A. M., Ferreira, I. M., Silva, A. M. O e., Nunes, T. P., Carvalho, M. G. de. (2018). Elaboração e avaliação da qualidade de geleia de umbu (Spondias Tuberosa Arr. C.) e mangaba (Hancornias Speciosa G.) com alegação funcional. Revista Segurança Alimentar e Nutricional, 25 (3), 104-113.

Souza, R. S., Cuellar, J. P., Donadon, J. R., Guimarães, R. de C. A. (2019). Compostos bioativos em geleia de bocaiuva com maracujá. Revista Multitemas, 24 (57), 7994.

Silva, G.S.; Santos, S. P. S.; Barbosa, N. F. P.; Santos, R. G.; Bery, C. S.; Silva, G. F. (2015, outubro). Secagem e caracterização físicoquímica da uva crimson. Congresso Brasileiro de sistemas particulados, XXXVII ENEMP, São Carlos, São Paulo, Brasil.

Szczesniak, A. S. (2002). Texture is a sensory property. Food Quality and preference. 13, 215-225.

Tavares, J. T. de Q., Santos, C. M., De carvalho, L. A., Da silva, C. L. (1999) Determinação volumétrica de ácido ascórbico pelos métodos de Tilmans e Balemtine. Magistra, 7, 1-8.

Vieira, A. F., Constantino, J. S. F., Rodrigues, L. M. de S., Silva, L. P. F. R. da, Almeida, R. D. (2017). Avaliação físico-química e de textura instrumental de geleia mista de jabuticaba e pitanga. Revista Brasileira de Agrotecnologia, 7 (2), 407-410.

Waterhouse Andrew L. (2002). Polyphenolics: determination of total phenolics. In:
Wrolstad RE, editor. Current protocols in food analytical chemistry. New York: John Wiley.

Yang, B., Lu Y., Wu, Q., Yang, Q., Kan, J. (2020). Hovenia dulcis polysaccharides: Influence of multi-frequency ultrasonic extraction on struture, functional properties, and biological activities. International Journal of Biological Macromolecules.1-36, 2020.

Yang, B., Wu, Q., Luo, Y., Yang, Q., Chen, G., Wei, X., Kan, J. (2019). Japanese grape (hovenia dulcis) polysaccharides: New insight into extraction, characterization, rheological properties, and bioactivities. International Journal of biological Macromolecules.134, 631-644.

\section{Acknowledgment}

IF Southeast MG - Barbacena campus for granting a scientific initiation scholarship 